\title{
LARIANGI DAN IDENTITAS KALEDUPA
}

\author{
Oleh \\ Nur Israfyan Sofian ${ }^{\mathrm{x}}$ \\ NIDN: ooo8048602, rien_sofian@yahoo.co.id
}

\begin{abstract}
Abstrak
Tulisan ini mencoba menghadirkan Lariangi sebagai sebuah ritual tradisional masyarakat Kaledupa di Kabupaten Wakatobi, Sulawesi Tenggara. Seiring berjalannya waktu, lariangi ini mengalami pergeseran dari sebuah ritual tradisional menjadi sebuah seni pertunjukan yang dipengaruhi oleh berbagai faktor. Dengan memahami fungsinya sebagai sebuah representasi komunitas pemiliknya, Lariangi akhirnya bergeser fungsinya setelah melalui negosiasi, (I) masuknya Islam dan mempengaruhi tradisi Hindu yang mulanya ada dalam Lariangi, (2) peralihan bahasa yang terjadi seiring berjalannya waktu dan (3) pergeseran fungsi Lariangi serta peruntukkannya. Representasi ideologis akhirnya bergeser dalam Lariangi dan melahirkan kepaduan baru dalam peralihan kepercayaan masyarakat pemilik Lariangi sejak masa pra-Islam dan setelah hadirnya Islam. Hal ini pun tampak dalam masyarakatnya yang islami tetapi masih 'menjaga' tradisi Hindu sebagai satu-satunya jejak yang terdeteksi. Juga karena pengaruh ekspansi Kesultanan yang memiliki bahasa Wolio sebagai lingua franca menghilangkan jejak kehidupan kuno di masyarakat Kaledupa. Pada tahap ini Lariangi tidak dapat lagi menjadi representasi identitas utuh masyarakat Kaledupa.
\end{abstract}

Kata kunci: Lariangi, representasi, identitas

\section{Pendahuluan}

Lariangi Kaledupa dikenal luas sebagai sebuah pertunjukan tradisional yang dimiliki oleh masyarakat Pulau Kaledupa di Wakatobi Sulawesi Tenggara. Dipercaya telah berumur ratusan tahun, pertunjukan ini bahkan diduga telah lahir sebelum wilayah Pulau Kaledupa menjadi bagian dari Kesultanan Buton ${ }^{2}$. Mulanya, lariangi merupakan persembahan berupa pertunjukan tari yang dipentaskan di hadapan Sultan maupun tamu-tamu Sultan maupun diperuntukkan bagi serdadu yang akan berangkat atau pulang dari perang.

Secara harfiah, kata Lariangi berasal dari dua suku kata yaitu lari yang artinya berhias dan angi yang artinya menyampaikan pesan. Sehingga Lariangi

${ }^{\mathrm{I}}$ Dosen Sastra Inggris FIB UHO

${ }^{2}$ Wawancara dengan Suhaidi, pemukul Gong untuk musik pengiring Lariangi,

2 Desember 2011 . 


\section{LARIANGI DAN IDENTITAS KALEDUPA}

itu sendiri bermakna orang-orang yang berhias untuk menyampaikan sebuah pesan yang dikandung dalam pertunjukan dan senandung yang dinyanyikan oleh para penari ${ }^{3}$. Menilik hakikat makna nama, jelaslah bahwa Lariangi bukan sekedar tari. Lariangi sebagai media penyampai pesan, merupakan rangkaian informasi yang mengandung makna tertentu yang dipantulkan oleh gerak, irama musik pengiring, kostum serta senandung yang membentuk kepaduan menjadi satu kesatuan yang utuh.

Senandung Lariangi merupakan pesan-pesan yang ingin disampaikan itu sendiri. Bahasa yang digunakan awalnya adalah bahasa Kaledupa kuno yang hanya dipahami oleh sedikit orang saja. Bahkan, beberapa penari lama (sepuh, dan sekarang telah menjadi pelatih) yang masih menghafalkan senandungnya, sudah tidak memahami lagi arti kata pada lagu lariangi secara literal. Namun di zaman pasca-Islamisasi, senandung yang dilantunkan oleh para penari menjadi berbeda. Isinya sebagian besar diartikulasi dalam bahasa Kaledupa yang lebih muda, bercampur dengan bahasa $\mathrm{Wolio}^{5}$ dengan dialek Kaledupa serta diawali dengan Shalawat yang kental unsur keislamannya (Sofian: 2014).

Gerak dalam Lariangi adalah gerak yang menunjukkan perempuan Kaledupa yang menggambarkan memiliki kekuatan. Kostum dan atribut yang digunakan menguatkan gerak yang juga mengandung pesan yang tersirat yang akan disampaikan sebagai sebuah teks. Musik pengiring juga menunjukkan kedekatan lahirnya Lariangi dengan masa Pra-Islam karena perangkat yang digunakan tidak jauh berbeda dengan musik pengiring tarian Jawa.

Masyarakat Kaledupa yang merupakan komunitas pemilik tarian tradisi ini, menempati posisi istimewa dalam hubungannya sebagai bagian Kesultanan Buton. Kata kaledupa berarti wangi dupa. Pulau ini kemudian diketahui berpenghuni ketika rombongan pelaut mencium wangi dupa. Sehingga oleh mereka, pulau tersebut diberi nama, kahedupa dan kemudian lebih dikenal

\footnotetext{
${ }^{3}$ Laman blog Syaiful Syaehu

${ }^{4}$ Setidaknya, belum diperoleh informasi tentang asal muasal bahasa Kaledupa kuno ini.

${ }^{5}$ Bahasa Wolio, bahasa penghubung yang digunakan di wilayah Kesultanan Buton karena wilayahnya tersebar luas di wilayah jazirah tenggara Sulawesi dan memiliki 8 bahasa berbeda dengan ratusan dialek.
} 


\section{LARIANGI DAN IDENTITAS KALEDUPA}

dengan sebutan Kaledupa ${ }^{6}$. Dupa, amat dekat hubungannya dengan ritual sembahyang bagi tradisi umat Hindu. Lariangi dalam unsur-unsurnya pun menyajikan kepaduan antara ritual Hindu dan Islam yang sangat kental, nampak dari gerak dan senandungnya. Arwah leluhur yang dikenal dengan sebutan sumanga sering dibuatkan sesaji ${ }^{7}$ oleh masyarakat setempat. Ritual menyampaikan sesaji ini disebut Haroa. Sebagai ritual tradisi yang amat dekat dan sehingga dapat diasosiasikan dengan tradisi Hindu, pelaksanaan ritual ini menimbulkan kesan berbeda karena dilaksanakan di bulan-bulan Islam yang penting seperti Rabiul Awal (bulan kelahiran Muhammad), Rajab, Sya'ban bahkan ketika hari pertama di bulan Ramadhan.

Wilayah Kaledupa merupakan salah satu wilayah taklukan Kesultanan Buton yang kemudian ditetapkan sebagai salah satu dari empat vassal yang ada di Kesultanan Buton. Mengingat posisinya sebagai sebuah vassal yang bertanggung jawab penuh atas pertahanan negeri, pulau ini juga mendirikan sebuah benteng pertahanan di sebuah bukit ${ }^{8}$. Lahir dari komunitas yang kemudian dipercaya sebagai tulang punggung pertahanan dalam negeri dan menjadi tarian pengantar serta penyambut serdadu perang, tarian Lariangi akhirnya mengartikulasikan kemampuan bertahan yang signifikan dengan tugas daerah pulau Kaledupa dalam posisinya sebagai bharata Kesultanan Buton, dan tampak dari kostum yang digunakan oleh para penari. Selain itu juga, Lariangi menjadi salah satu pertunjukan yang paling menonjol dan bertahan sebagai tari tradisi yang lahir dari masyarakat Kaledupa pada khususnya dan Wakatobi pada umumnya. Bahkan sebagai salah satu seni tradisi yang hadir di masa Pra-Islam, Lariangi menjadi salah satu pertunjukan tari yang dapat bertahan dibandingkan dengan beberapa pertunjukan tradisi lain yang pernah ada. Meski beberapa waktu yang lalu, ketika Kaledupa masih

\footnotetext{
${ }^{6}$ Abubakar, Budayawan Buton. Dalam sebuah artikel di majalah lokal, Wolio Molagi (terbit sekitar akhir tahun $1990-$ an)

${ }^{7}$ Sesajian dimaksud berupa beberapa jenis penganan khas Buton dan dilengkapi dengan 2-3 batang rokok (yang digulung dan diisi tembakau secara manual) beserta perlengkapan sirih.

${ }^{8}$ Benteng pertahanan ini berada di sebuah bukit di Kaledupa yang dibuat berdasarkan aturan sufistik yang berlaku di pusat Kesultanan Buton di Bau-Bau. Informasi ini diperoleh dari sebuah wawancara singkat dengan sesepuh adat dari daerah Jamaraka, pusat Kerajaan kuno Kaledupa.
} 


\section{LARIANGI DAN IDENTITAS KALEDUPA}

menjadi bagian dari wilayah Kabupaten Buton ${ }^{9}$, lariangi hanya sempat muncul sebentar di beberapa even tertentu lalu tenggelam. Atau paling tidak, hanya ditampilkan oleh segelintir orang saja.

Lariangi adalah produk budaya yang diturunkan oleh beberapa penari sepuh dengan menyelenggarakan semacam kursus menari di setiap desa yang ada di Kecamatan Kaledupa. Oleh pemerintah daerah setempat, para pelaku yang terdiri dari penari perempuan dan penari laki-laki, pemain alat musik pengiring, serta pelatih, (hanya) difasilitasi ketika mendapat undangan untuk tampil di even-even tertentu yang sifatnya regional. Bahkan, lariangi ini menjadi sebuah persembahan bagi penyambutan hadirnya tamu-tamu yang berkunjung ke wilayah Wakatobi. Akhirnya lariangi kemudian disuguhkan bagi siapapun yang datang. Dari sebuah tari yang hanya diperuntukkan sebagai sebuah persembahan di istana, kemudian dipertunjukan bagi siapa saja yang memiliki kemampuan finansial untuk membayar atau memfasilitasi pertunjukan ini.

Penelitian ini akan melihat Lariangi sebagai sebuah identitas budaya bagi masyarakat Kaledupa. Lariangi sebagai sebuah teks merupakan representasi komunitasnya karena representasi itu sendiri menurut Melanie Budianta adalah "imaji atau penyajian kembali kenyataan dalam bentuk visual dan verbal yang menyiratkan makna dan ideologi tertentu" ${ }^{\text {Io }}$. Tugas ideologis masyarakat Kaledupa adalah benteng pertahanan timur terluar Kesultanan Buton dan Lariangi adalah bentuk visual yang disajikan sebagai interpretasi gambaran pertahanan tersebut. Masyarakat Kaledupa yang merupakan intisari dari sebuah artikulasi yang ingin disampaikan oleh Lariangi dalam satu kesatuan sebagai sebuah pertunjukan tradisi. Lariangi tidak lahir dari sebuah keadaan yang tiba-tiba saja dan kemudian berproses tanpa ada sebuah muatan dalam posisinya sebagai sebuah teks, "come from somewhere, have histories" Identitas masyarakat Kaledupa yang turut pula ingin disampaikan dalam salah

${ }^{9}$ Zuhdi, Sejarah Buton yang Terabaikan Labu Rope Labu Wana, 2010: I. Wilayah Kabupaten Buton adalah juga wilayah eks-Kesultanan Buton. Di tahun 2003,ketika otonomi daerah, beberapa wilayah tertentu memisahkan diri dan menjadi sebuah kabupaten sendiri, salah satu di antaranya adalah Kabupaten Wakatobi.

${ }^{10}$ Melanie Budianta dalam "Perempuan Seni Tradisi: Kontestasi dan Siasat Lokal” artikel oleh Novi Anoegrajekti

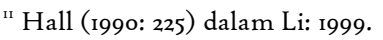




\section{LARIANGI DAN IDENTITAS KALEDUPA}

satu produk budaya yakni Lariangi, akhirnya dapat dipahami baik oleh masyarakat Kaledupa itu sendiri atau komunitas di luar mereka, karena identitas budaya, oleh Hall dilihat dalam cara pandang yang ... "Not an essence but positioning" ${ }^{12}$. Sehingga lariangi, di samping merupakan sebuah jenis tari tradisi, bagaimana produksi pesan dan sejauhmana makna pesan tersebut sampai kepada penerima adalah salah satu bagian yang akan menjadi perhatian penelitian ini.

\section{Interpretasi Tarian Lariangi}

Lariangi seperti telah disebutkan di atas adalah sebuah pertunjukan tradisi yang lahir sejak masa pra-Islam dan lalu bertahan di zaman Kesultanan yang memiliki kualitas keIslaman yang sangat kental. Bahkan Lariangi masih eksis dan dapat dengan mudah dijumpai di masyarakat modern saat ini. Pertunjukan Lariangi melibatkan sepuluh orang penari perempuan, dua orang laki-laki sebagai penari pengiring (ngibing) -mereka selalu hadir di sesi kedua pertunjukan Lariangi- beserta beberapa orang pemain musik pengiring. Alat musik pengiring Lariangi adalah Mbololo (gendang besar), Tawa-Tawa (Gong kecil), Ndengu-ndengu (Kenong) dan Ganda (Gendang) ${ }^{13}$. Keempat alat musik pengiring ini sangat umum digunakan dalam pertunjukan beberapa tarian yang berasal dari Jawa.

Pertunjukan lariangi terdiri dari dua sesi. Sesi pertama adalah tampilnya semua penari perempuan secara bersamaan. Pada sesi kedua, hanya ada dua penari yang menari seperti biasa sambil kedua ngibing meng”orbit” seperti adegan silat mengelilingi mereka (delapan lainnya duduk dan juga akan menari seperti dua penari lainnya). Lariangi dimulai dengan masuknya sepuluh gadis penari ke atas panggung. Para penari masuk satu persatu sambil diiringi musik lalu membentuk dua baris berbanjar ke belakang. Setelah formasi awal terbentuk, semua penari lalu meletakkan kipas dan selendang masing-masing di kanan dan kiri- di atas lantai. Lalu musik pengiring mulai melambat dan para penari mulai memeragakan gerakan tubuh, yang serupa

\footnotetext{
${ }^{12}$ Ibid

${ }^{13}$ Laman blog kaledupa-hoga, diakses 20 Oktober 2011 pukul 20.18 wita.
} 


\section{LARIANGI DAN IDENTITAS KALEDUPA}

dengan tata cara sembahyang sesuai tradisi religius yang sangat Hindu yakni dengan mengatupkan kedua tangan di atas dahi, sebagai pembuka. Setelah itu, mereka mulai mengambil kedua atribut tadi yakni kipas dan selendang. Sambil mulai bersenandung bersahut-sahutan mereka memeragakan tari yang tampak seolah-olah hendak mempertahankan diri dengan kipas sebagai "tameng"nya. Senandung yang dinyanyikan oleh semua penari diawali dengan Shalawat yang kental dengan tradisi Islam-. Kedua ritual penyembahan tadi, perpanduan proses penyembahan yang dipengaruhi oleh tradisi Hindu dan adanya Shalawat tadi, merupakan gambaran yang ideal tentang kedekatan orang Kaledupa dengan sang Pencipta yang terbentuk melalui proses akulturasi yang sangat dominan.

Tampaklah tata cara yang mereka gunakan adalah perpaduan yang sangat kental antara Hindu sebagai kepercayaan yang mula-mula dan Islam yang hadir kemudian. Gerak para penari dalam memainkan tangan kiri yang mengapit selendang dengan jari-jari serta tangan kanan yang memegang kipas menunjukkan tata cara mempertahankan diri dengan cara yang sangat gemulai. Ketika kedua penari laki-laki masuk, tempo musik pengiring akan menjadi lebih cepat, dan penari perempuan pun melakukan gerakan tari yang sama seperti dalam sesi pertama tadi (kecuali adegan menyembah). Selendang para penari akan diambil oleh para ngibing yang akan diselipkan sejumlah uang tanpa adanya patokan jumlah. Sehingga, pada akhirnya kedua ngibing yang disiapkan tadi, hanya menjadi pemanis saja. Seolah mengajari para tamu bagaimana harusnya mengiringi kedua penari ini. Para penari pun, seolah mendapat bonus saweran dari pertunjukan sakral ini.

Di Kaledupa saat ini, lariangi selalu dipertunjukkan setidaknya setahun sekali. Setiap desa dan sekolah menengah akan berlomba-lomba mengirimkan delegasinya untuk menjadi peserta kegiatan semacam festival yang diadakan untuk turut memeriahkan hari kemerdekaan. Setiap penari sepuh juga sibuk mengajarkan dan meminta para calon penari untuk menuliskan senandung yang akan dinyanyikan sebagai salah satu bagian penting pertunjukan lariangi. 


\section{LARIANGI DAN IDENTITAS KALEDUPA}

Senandung lariangi yang berasal dari bahasa Kaledupa kuno tersebut dituliskan kembali ke dalam aksara latin yang umum oleh calon penari.

Jika awalnya tarian ini hanya dipertunjukan pada saathadirnya tamu Sultan, maka kemudian tradisi ini selalu dipertunjukan pada malam-malam tertentu menjelang pernikahan kerabat kaum terpandang di wilayah Kaledupa. Hal ini dimaksudkan demi menjaga agar kesenian tradisi ini tetap hidup. Di samping itu juga dimaksudkan karena pernikahan adalah saat memasuki gerbang hidup sebenarnya yang terkadang diwarnai oleh "perang batin" bagi para pelakunya. Saat itu, peran Lariangi hanyalah sekedar menghibur karena biasanya yang menjadi penari adalah para penari yang kini sudah menikah. Mereka juga menyadari untuk tidak utuh menggunakan atribut penari lariangi yang sesungguhnya mengingat salah satu persyaratan menjadi penari lariangi adalah gadis perawan.

Sejak melepaskan diri dari wilayah Kabupaten Buton di sekitar tahun 2005 dan menjadi kabupaten sendiri, Kabupaten Wakatobi mulai gencar menyibukkan diri membangun di berbagai macam sektor, termasuk pariwisata. Wakatobi adalah sebuah kabupaten yang berupa kepulauan dengan lima pulau besar dan beberapa pulau kecil. Sebagian besar wilayahnya berupa lautan dengan waktu tempuh setidaknya satu jam dari pulau yang satu ke pulau yang lainnya. Memusatkan pembangunan kantor-kantor pemerintahan di satu pulau saja yaitu Wangi-Wangi, sempat menjadi kebijakan yang kurang berterima oleh penduduk di pulau yang lainnya. Namun mengingat akses ke wilayah kabupaten lain, kebijakan ini akhirnya dapat diterima oleh seluruh masyarakat Wakatobi. Wangi-Wangi akhirnya dipilih sebagai pusat pemerintahan sedang pulau lainnya dipusatkan berdasarkan potensi wilayahnya seperti Kaledupa untuk pusat penelitian dan Tomia sebagai pusat pariwisata. Namun yang berkembang kemudian, Kaledupa tidak hanya menjadi pusat penelitian ${ }^{\mathrm{I} 4} \operatorname{tapi}$ juga menjadikan wisata alam dan budaya sebagai magnetnya. Setiap tahunnya

${ }^{14}$ Penelitian ini biasanya melibatkan peneliti asing yang sebagian besar adalah mahasiswa $\mathrm{S}_{\mathrm{I}}$ dari beberapa Universitas di Inggris dan Amerika. Mereka meneliti untuk kebutuhan skripsi. 


\section{LARIANGI DAN IDENTITAS KALEDUPA}

daerah ini dikunjungi setidaknya $200^{15}$ peneliti asing dan volunteer ${ }^{16}$ yang umumnya berasal dari Inggris dan Amerika serta beberapa negara lainnya.

Lariangi pun menjadi salah satu komoditas yang dijadikan sebagai modus untuk menarik para pelancong dari sisi wisata budaya. Dalam kurun waktu dua bulan, lariangi setidaknya ditampilkan sebanyak tiga kali untuk menyambut para tamu. Lariangi sebagai sebuah tarian sakral yang awalnya dipertunjukan dalam lingkungan kerajaan sebagai penyampai pesan bagi para tamu formal Kesultanan, kini menjadi suguhan penyambut tamu baik formal maupun informal.

Mengingat persyaratan untuk menjadi penari lariangi, tidaklah mudah untuk menjadi bagian dari lariangi. Harus memiliki bentuk badan dan suara yang terkualifikasi menurut aturan tertentu yang hanya diketahui oleh para pelatihnya, membuat tarian ini menjadi sakral dan hanya dipertunjukan pada momen dan tempat tertentu. Sebagai perbandingan, seorang Ronggeng ${ }^{17} \mathrm{di}$ Dusun Dukuh Paruk ditunjuk melalui pemberian sebuah keris secara ghaib. Atau misalkan penari Tayub di Nganjuk, yang mendapatkan wisik terlebih dahulu sebelum akhirnya dapat menjadi penari Tayub yang bersinar ${ }^{18}$. Meskipun penari lariangi tidak melalui wangsit atau hal mistik semisal Tayub, cikal bakal penari Lariangi juga nampak dari kecil dari bentuk badan dan irama suara. Seorang penari lariangi yang sudah memasuki usia yang sepuh biasanya telah dapat mengidentifikasi setiap gadis kecil yang dianggap berbakat untuk menarikan tarian tersebut. Ini dimaksudkan karena menjadi penari Lariangi tidaklah hanya harus masih perawan -karena jenis pakaian yang dikenakan adalah pakaian yang khusus bagi perawan- tapi juga karena tanggung jawab atas pesan yang harus tersampaikan bagi siapapun yang menontonnya. Sekarang, setiap perempuan Kaledupa dapat menjadi penari Lariangi. Tak peduli apakah ia paham maksud yang ingin disampaikan oleh Lariangi dalam

\footnotetext{
${ }^{\text {is }}$ Di tahun 2009 bahkan, peneliti asing yang datang mencapai lebih dari 200 orang dalam satu minggu

${ }^{16}$ Volunteer di sini adalah siswa ataupun mahasiswa asing yang datang berjalan-jalan dan menikmati liburan di Pulau

Hoga -sebuah pulau kecil di depan Pulau Kaledupa-dan biasanya mereka secara sukarela bersama-sama turut membantu para peneliti di sela-sela liburan mereka.

${ }^{17}$ Dalam Film Sang Penari

${ }^{18}$ Roestopo, 2003: 173. "Mencermati Seni Pertunjukan I".
} 


\section{LARIANGI DAN IDENTITAS KALEDUPA}

gerakan dan senandungnya. Hal demikian adalah sebuah ironi yang melenceng dari niat awal dan kesakralan hakikat lariangi.

Bahkan kini, orang dari luar Kaledupa pun dapat saja belajar untuk menarikan lariangi. Masalahnya adalah jika saja seorang gadis yang tidak berasal dari Kaledupa akan menarikan tarian ini, identitas apakah yang akan dibawanya? Sementara dalam lariangi, seseorang yang menarikan lariangi tidak saja akan menyampaikan pesan tentang strategi perang dan pertahanan tapi juga identitasnya sebagai seorang wanita Kaledupa. Identitas yang dimaksud adalah berupa derajat kebangsawanan yang ditunjukkan oleh kostum yang digunakan. Identitas kebangsawanan dalam kostum penari lariangi adalah berupa gelang dan sarung pelapis yang digunakan. Jumlah gelang yang digunakan oleh penari lariangi dari kalangan bangsawan berjumlah empat di masing-masing pergelangan tangannya. Sedang penari lariangi yang berasal dari kalangan nonbangsawan hanya boleh menggunakan dua buah gelang saja. Sementara jenis sarung pelapis pun dapat mengidentifikasikan strata sosial sang penari yakni sarung Boke ${ }^{19}$ bagi bangsawan dan Kasopa ${ }^{20}$ bagi yang bukan bangsawan. Seiring berjalannya waktu, hal seperti ini tidak lagi dianggap menjadi hal yang perlu mendapat perhatian. Tidak adanya kepedulian tentang konsepsi ini turut menjadikan lariangi hanya sebagai sebuah tontonan untuk menghibur audiensnya. Padahal lebih dari itu, lariangi sebenarnya adalah sebuah arena yang mempersatukan derajat sosial yang berbeda dalam sebuah panggung khusus dalam suasana yang lebih dekat. Pesan yang disampaikan tidak hanya berupa semangat dan tatacara bertahan tetapi betapa bersatu tanpa memperdulikan perbedaan adalah pula senjata ampuh untuk menjembatani jurang pemisah.

Selain itu, lirik dalam senandung lariangi mulanya menggunakan Bahasa Kaledupa kuno yang 'diduga' berasosiasi dengan Hinduisme yang ada di komunitasnya. Ketika Islamisasi memasuki wilayah Kaledupa, lirik dari senandungnya disisipi oleh paham keIslaman yaitu Shalawat. Lebih dari itu,

\footnotetext{
${ }^{19}$ Sarung adat Buton Kaledupa, bermotif garis dengan spasi antar garis yang agak besar (wawancara dengan mantan penari Lariangi, 7 Desember 2oII)

${ }^{20}$ Seperti Boke, hanya saja spasi antar garis lebih kecil
} 


\section{LARIANGI DAN IDENTITAS KALEDUPA}

bahasa kuno milik masyarakat Kaledupa kuno pun seolah ingin dimudahkan dengan menjadi Bahasa Wolio meski dengan dialek Kaledupa yang berayun. Hal ini seperti hendak menghilangkan jejak Hindu, tidak saja di wilayah Kaledupa tetapi di seluruh wilayah eks-Kesultanan Buton. Karena hingga kini, hampir tidak ditemukan lagi situs-situs ataupun artefak-artefak yang menunjukkan bahwa pernah ada kehidupan masyarakat penganut Hindu di wilayah eks-Kesultanan Buton kecuali yang sifatnya tak dapat disentuh, misalkan pelaksanaan Haroa dan bentuk sesajen yang digunakan. Padahal dalam beberapa referensi Kesultanan Buton, ada hubungan yang sangat dekat antara Buton dan Majapahit ${ }^{21}$ yang menganut $\mathrm{Hindu}^{22}$. Hal-hal yang berkenaan dengan Kaledupa di masa Pra-Islam seperti hendak disembunyikan dengan peralihan bahasa ini. Karena dalam lirik senandungnya terdapat pesan khusus yang sebenarnya ingin disampaikan oleh para leluhur bangsa Kaledupa. Bahkan dengan datangnya tamu asing ${ }^{23}$ ke Kaledupa, bahasa yang digunakan dalam lirik senandungnya pun kini mulai beralih ke pantun modern berbahasa Indonesia yang dinyanyikan dengan dialek Kaledupa. Pesan ideologis yang direpresentasikan dalam Lariangi akhirnya pudar dan hampir tak terdeteksi lagi jejaknya. Lariangi yang semestinya membawakan informasi tentang komunitas masyarakat Kaledupa yang utuh hampir tak terjiwai lagi dalam tarian tersebut.

Tidak dapat dipungkiri program mempopulerkan Lariangi dengan mengakrabkannya dengan dunia di luar komunitasnya merupakan bagian dari usaha warga setempat untuk terus menghidupkan Lariangi. Proses itu kemudian tidak saja di pentas lokal tapi juga di arena yang lebih luas. Usaha ini bahkan tidak hanya melibatkan setiap desa tapi juga sekolah menengah dan dasar di Kaledupa. Hampir semua instansi yang melibatkan gadis-gadis muda di dalamnya memiliki grup tari Lariangi masing-masing. Setiap desa,

\footnotetext{
${ }^{21}$ Dalam kitab Negarakertagama dituliskan bahwa Buton turut pula menjadi bagian dari kekuasaan Majapahit

${ }^{22}$ Raja Buton keempat bernama Tua Rade dipercaya memiliki darah Jawa dan pernah membuktikannya ketika berkunjung ke Majapahit. Pada saat itu dalam sumpahnya Tua Rade mengatakan ia adalah keturunan Jawa dari ayahnya bernama Bataraguru yang berasal dari bangsawan Jawa.

${ }^{23}$ Asing di kalimat ini mengandung makna umum yaitu orang -orang dari luar Kaledupa ataupun orang-orang yang tak memahami bahasa Kaledupa.
} 


\section{LARIANGI DAN IDENTITAS KALEDUPA}

memusatkan latihan tari ini di rumah seorang penari yang sudah sepuh. Setiap sekolah menengah dan dasar, memfasilitasi program latihan setiap harinya. Tidak hanya festival yang menjadi target panggungnya tapi juga untuk memenuhi permintaan hadirnya tamu asing yang datang ke wilayah ini yang selalu menggilir permintaan tampil yang ditujukan bagi kelompok tari dari setiap dusun.

Dilihat dari proses pada masyarakat Kaledupa, Lariangi mulanya adalah sebuah ritual yang hanya dilaksanakan pada waktu tertentu tetapi kini menjadi lebih cair dalam masyarakat sebagai satu ekspresi seni dan komunikasi. Peristiwa yang melatari pelaksanaan ritual ini pun adalah peristiwa yang memiliki keterkaitan erat dengan kehidupan mereka sebagai orang Kaledupa. Namun seiring berkembangnya waktu, tarian ini bergerak dari sebuah ritual, kini mulai memasuki peran yang menurut Kusmayanti sebagai seni pertunjukan tradisi yang turut mengalami pergeseran dalam apresiasi ${ }^{24}$. Ritual yang berupa tarian persembahan kini menjadi sebuah tarian yang diproduksi secara massive dan massal. Faktor konservasi oleh pemerintah setempat maupun masyarakat untuk menjaga kelangsungan tradisi ini tetap terjaga dalam komunitasnya dimuati faktor ekonomi yang lebih dominan. Tidak dapat dipungkiri jika ekonomi turut pula berkontribusi positif mengingat bertahan pun harus dengan dukungan faktor ekonomi yang bijak.

\section{Penutup}

Lariangi adalah ritual tradisional masyarakat Kaledupa di Kabupaten Wakatobi, Sulawesi Tenggara. Berdasarkan makna harfiah, kata Lariangi yang berarti menyampaikan pesan, jelaslah bahwa Lariangi bukan sekedar tari. Lariangi sebagai media penyampai pesan, rangkaian informasi yang mengandung makna tertentu yang dipantulkan oleh gerak, irama musik pengiring, kostum serta senandung yang membentuk kepaduan menjadi satu kesatuan yang utuh. Gerak dalam Lariangi adalah gerak yang menghadirkan perempuan Kaledupa yang menggambarkan memiliki kekuatan. Kostum dan

\footnotetext{
${ }^{24}$ Kusmayanti, 2003. "Mencermati Seni Pertunjukan I"
} 


\section{LARIANGI DAN IDENTITAS KALEDUPA}

atribut yang digunakan menguatkan gerak yang juga merupakan sebuah pesan yang tersirat dalam Lariangi. Di sini Lariangi adalah sebuah teks merupakan representasi komunitasnya.

Seiring berjalannya waktu, tarian ini mengalami pergeseran dari sebuah ritual tradisional menjadi sebuah seni pertunjukan. Sebagai sebuah representasi komunitas pemiliknya, Lariangi mengalami pergeseran fungsi, diantaranya setelah masuknya Islam dan mempengaruhi tradisi Hindu yang mulanya mewarnai bentuk dan gerak Lariangi. Di samping itu peralihan bahasa karena pengaruh ekspansi Kesultanan Buton yang mengharuskan penggunaan bahasa Wolio sebagai lingua franca. Hal ini menghilangkan jejak "bahasa kuno" di masyarakat Kaledupa.

Akhirnya pergeseran Lariangi yang semula berfungsi sebagai tari tradisi ritual dan gelarannya dikhususkan kepada para serdadu perang di hadapan sultan, kini menjadi seni pertunjukan yang digelar dalam waktu dan tempat yang tidak ditetapkan lagi. Terlebih, peruntukkan Lariangi tidak mengkondisikan kesakralan mulanya namun lebih sebagai komoditas wisata dan penghormatan kepada pejabat daerah. Pada tahap ini, jelas bahwa Lariangi sebagai identitas masyarakat Kaledupa kehilangan momen untuk mengartikulasikan dirinya dan terutama ia tidak dapat lagi menjadi representasi ideologi masyarakat Kaledupa sebagai pemilik tradisi. 


\section{LARIANGI DAN IDENTITAS KALEDUPA}

\section{Daftar Acuan}

Abubakar. (tahun tidak ada). Sebuah artikel dalam Majalah Budaya Wolio Molagi. Bau-Bau.

Budianta dalam "Perempuan Seni Tradisi: Kontestasi dan Siasat Lokal", makalah oleh Novi Anoegrajekti. Di sajikan pada diskusi "Perempuan dalam Citra Visual dan Pertunjukan” di Komunitas Salihara, Kamis 21 April 201 I.

Hall dalam "Articulating Indigenous Identity in Indonesia: Resource Politics and the Tribal Slot” oleh Tania Murray Li. Artikel dalam buku kumpulan artikel Seminar Teori dan Metodologi Ilmu Pengetahuan Budaya (Materi Kuliah Program Doktoral FIB UI, 20II).

Kaledupa-Hoga Grup at http://kaledupahoga.blogspot.com/20II/og/sinopsistari-lariangi.html. diakses 20 Oktober 20II, pukul 20.18 wita.

Kusmayati, A.M. Hermien. Sebuah artikel, Seni Pertunjukan Ritual:Tumbuh dan Kembang ke Arah Mana. 2003. Mencermati Seni Pertunjukan I. STSI Surakarta: Surakarta.

Roestopo. Sebuah Artikel, Ritual "Baru”: Pertunjukan Ritual yang Dipolitisasi. 2003. Mencermati Seni Pertunjukan I. STSI Surakarta: Surakarta.

Saehu, Syaiful at http://syaifulsaehu.blogspot.com/2010/1o/tari-lariangi.html. diakses 29 Oktober 20II, pukul 20.18 wita.

Sofian, Nur Israfyan Sofian. 2014. Lariangi Pada Masyarakat Kaledupa Di Wakatobi Sulawesi Tenggara: Tinjauan Pewarisan. Tesis: Universitas Indonesia. Tidak diterbitkan.

Zuhdi, Susanto. 2010. Sejarah Buton yang Terabaikan Labu Rope Labu Wana. Rajawali Pers: Jakarta. 